\title{
LEGAL PROTECTION OF THE CREDITOR ON FIDUCIARY GUARANTEE OBJECTS UNLISTED IN THE FIDUCIARY REGISTRATION OFFICE
}

\author{
Sanusi \\ Dosen UPS Tegal \\ Ssanusi364@gmail.com
}

\begin{abstract}
Abtract
The aim of this study was to analyze the legal protection of the creditor and their weaknesses on the fiduciary guarantee objects unlisted in the current Fiduciary Registration Office. This study is a normative legal research or also called doctrinal legal research. This research will use facts that describe the legal protection of the creditor on the fiduciary guarantee objects unlisted in the current fiduciary registration office, the weaknesses of legal protection of the creditor on the fiduciary guarantee objects unlisted in the current fiduciary registration office, and the reconstruction of the legal protection of the creditor on the fiduciary guarantee unlisted in the fiduciary registration office based on the value of justice. The result of the research is that the Government should immediately establish the Supervisory Agency and Execution of Fiduciary Guarantee Objects based on Government Regulation in Lieu of Law and other legislation.
\end{abstract}

Keywords: Fiduciary, Legal Guarantee, PPAT, notary.

\section{A. Introduction}

The guarantee institution is a requirement of the community of economic actors and business actors. Trust becomes the basis of the agreement which is reinforced with the more concrete guarantee. A guarantee as a legal institution generates the legal principles regulated in the civil law that has an important position in economic law. ${ }^{1}$ This guarantee institution varies between collateral, such as mortgage and

1 Sri Rejeki Hartino, 2007, Hukum Indonesia, Banyumedia Indonesia Publishing, Malang, page, 163-164. 
fiduciary. There is also a guarantee of borgtoch, which consists of the corporate guarantee and personal guarantee.

In Article 1 paragraph (1) of Fiduciary Guarantee Act is the transfer of ownership rights of an object on the basis of trust that the rights of ownership transferred remain in the possession of the object owner. Thus, the fiduciary arises on the basis of society's need for credit with the assurance of moving objects; however, those objects are needed for their own use. If someone used a pawnshop, the objects cannot be used because of the inbezitstelling requirement (Article 1152 paragraph (2) Book of Civil Code). It is stated that the existence of the obligation to release physical objects from the existence of the lender to the recipient / holder Pledge. Terms of such mortgage is felt very heavily by the giver of the pawn if the objects that will be guaranteed are needed to sustain daily life, especially in order to run businesses such as restaurants, bus companies, trucks, taxis and others.

Fiduciary has important meaning in fulfilling credit requirement for society, especially small and medium enterprise because it is very helpful to debtor's business. The debtor can still control the guarantee objects for the daily business and the banking practically. It is because the Bank does not need to provide a special place such as in pawn institutions (pand)". ${ }^{2}$ In the pledge agreement, the guarantee objects should be delivered to the Creditor in accordance with Article 1150 paragraph (2) of the Civil Code: "Pawn is a right earned by a debtor of

${ }^{2}$ Sri Soedewi Mascjhoen Sofwan, 1977, Beberapa Masalah Pelaksanaan Lembaga Jaminan Khususnya Fidusia di Dalam Praktek dan Pelaksanaannya di Indonesia, Fakultas Hukum Universitas Gajah Mada, Yogyakarta, page 75. 
a moving object which is handed over to him by a debtor or by another person whose name is ... ". The terms of the mortgage when applied to the bank may cause problems regarding storage, especially for the banks in the big city. It is happened in the absence of widespread warehouses at their disposal. ${ }^{3}$ As a result of this too narrow mortgage arrangement, fiduciary was generated to fill the void of guarantee law.

Based on the observation of the author, the application of the fiduciary agreement to the creditor party stops only in the making of credit agreements and authentic deeds only and is not registered to the Fiduciary Registration Office. In addition, the negotiation is often done by providing the additional fees to the fiduciary recipients when executing fiduciary guarantee objects. In providing a legal certainty as a form of legal protection, it is required a rule of law. In fact, in the practice, the Creditor always gets disadvantaged by the debtor who breaches the contract.

The registration process of fiduciary guarantee certificate is regulated in Article 11 until Article 18 Fiduciary Guarantee Act. However, to improve the service of fiduciary guarantee registration easily, quickly and low cost, it is necessary to conduct electronic fiduciary guarantee service registration. According to this, the Government then approved Government Regulation Number 21 of 2015 on Procedures for Fiduciary Guarantee Registration and Fiduciary Guarantee Deed Making Cost (online registration).

3 J. Satrio, 2002, Hukum Jaminan, Hak-Hak Jaminan Kebendaan, Citra Aditya Bakti, Bandung, page 149. 
This research is a normative legal research or also called doctrinal legal research. ${ }^{4}$ This research is a qualitative research. It will use the facts that describe the legal protection of the creditor on the fiduciary guarantee objects unlisted in the current fiduciary registration office. The qualitative normative legal research is concerned more on the understanding of the existing data rather than the quantity or amount of data. Along with that, it is attributed to the discipline of law. This research is also called normative juridical research. Hence, this research always refers to the principles of law, legislation, jurisprudence and legal doctrines which focus on the research of literature in the field of law by using existing materials.

\section{B. Discussion}

\section{Legal protection of the creditor on the fiduciary guarantee objects unlisted in the current fiduciary registration office}

Fiduciary Guarantee Act as mentioned in the sub c section aims to provide a more complete arrangement of the existing one. Moreover, it would provide better protection for the parties concerned. In the explanation of the Fiduciary Guarantee Act, beside to accommodate the needs, it also provides a legal certainty, therefore Fiduciary Guarantee Act take the principle of fiduciary guarantee registration. Registration is expected to provide legal certainty to the giver and the recipient or to the third party.

4 Ronny Hanitijo Soemitro, 1990, Metodologi Penelitian Hukum dan Jurimetri, Ghalia Indonesia, Jakarta, page 52. 
Registration is intended to have an effect on third parties. With registration, the third parties are considered to know the characteristic that attached to the object concerned and the existence of guarantee bond with the characteristics mentioned, and in terms of third parties is neglect to pay an attention/control the register/list, it can't expect the protection based on good intention and have to bear the risk of loss.

The guarantee object execution on the giving of bad credit with fiduciary warranty is performed if the tort caused by debtor's inability to its obligation as the last completion because the rescue effort is not successful. Fiduciary warranty execution system in article 29 UUJF determine if the debtor or fiduciary giver broke the promise, the execution against the object which becoming fiduciary warranty object it can be done by:

a) Title executorial implementation has the equal power with the court verdict which had the permanent law power.

b) The sales of the object which become fiduciary warranty over the power of the fiduciary receiver itself through public auction also take its debt repayment from the sales.

c) Over the counter sales which is done based on the deal of fiduciary receiver and giver, if in that way the highest price is obtained which benefits both parties.

The third of fiduciary warranty execution above have each difference on its implementation procedure. For execution which using title executorial based on fiduciary warranty certificate, the sales implementation of object guarantee is submissive and obedient toward 
The Law of Civil Event as prescribed in article 224 H.I.R, the implementation procedure takes a long time. The execution implementation of the fiduciary warranty object based on gross or title executorial of fiduciary warranty certificate, according to the criteria of article 196 H.I.R, start with the submission of execution implementation application by creditor (fiduciary receiver) to the head of district court concerned to run the execution of fiduciary warranty object, then the head of district court will call the debtor (fiduciary giver) and instruct to fulfill their obligation as soon as possible in 8 days, according to the article 196 H.I.R, the head of district court concerned will instruct the bailiff with warrant to confiscated a number of fiduciary warranty objects.

Execution with the sales of warranty object over the fiduciary warranty object able to be performed with two ways: parate execution through public auction and over the counter sales which the author will describe as follow: ${ }^{5}$

a) Parate execution through public auction (Sales through State Assets and Auction Service Office or auction house).

b) Outstanding credit based on the agreement which has been made with fiduciary warranty can be done. The billing over the credit is performed in two ways: billing outside the court and through the court.

c) Billing outside the court.

d) The credit recall can be done by billing, either directly by the bank without going through the court, or by third

\footnotetext{
${ }^{5}$ Winda Pebrianti, 2012, Legal Review Over Execution of Fiduciary Warranty Object through Parate Execution if the Guarantee Object Switch on Third Parties or Destroyed, Law Supremacy, Vol. 21, No 1, January 2012. Page. 87-91.
} 
parties. The recall effort through billing is not always smooth, sometimes several calls must be taken. The billing implementation to the debtor can be done by bank them or helped by third parties (service agent) or lawyer. The bank sent the official bill beforehand stated that the debtor has to pay off the outstanding credit and interest debt by specifying the time limit to pay it off. This official bill followed by some warning, especially if the debtor did not pay off or pay attention to the warning given.

\section{The weakness of creditor law protection over the fiduciary warranty object which is not registered with the current fiduciary registration office.}

The regulation of Fiducia (in Indonesian Undang-Undang Jaminan Fidusia) enactment is not maximally affecting the businessmen because the article 5 regulation of Fiducia (in Indonesian Undang-Undang Jaminan Fidusia) is about the provision of notarial deed toward fiduciary warranty imposition is not much implemented by the concerned parties. There are parties which use fiduciary warranty imposition with over the counter deed and did not fulfill the fiduciary warranty imposition standard. This caused by Undang-Undang Jaminan Fidusia (regulation of Fiducia in Indonesian) did not mention the strict sanctions if not made notarized. On its practice, some of finance institution/Leasing still using over the counter deed which did not meet the fiduciary warranty deed standard and specific banks also using over the counter deed to fiduciary warranty imposition of specific limits. It reflects not giving legal protection of each party and did not 
guarantee legal certainty. According to the author, the UUJF weakness is:

1) There is no strict sanction toward the fiduciary warranty binding done over the counter.

2) There is no strict sanction toward the using of "Sale Authority" which clearly contradicts with the execution ways according to UUJF so it is potentially does not give the sense of justice for the debtor.

3) The rampant usage of pledge authority on over the counter is potential conflict related to signature validity on its authority, except being legalized by a public notary of notary authority is made.

On 2013, Ministry of Justice and Human Rights launch online fiduciary warranty registration administration system. It is marked by the issuance of Indonesian Justice and Human Right Ministerial Regulation Number 9 Year 2013 about the enforcement of online fiduciary warranty registration and Indonesian Justice and Human Right Ministerial Regulation Number 10 Year 2013 about online fiduciary warranty registration procedure which is updated with Indonesian Justice and Human Right Ministerial Regulation Number 21 year 2015 about fiduciary warranty registration procedure and fiduciary warranty deed issuance cost. The aim of online fiduciary warranty registration enactment is to improve the legal service of fiduciary warranty registration easily, quickly, cheap, and convenient, so the application of fiduciary warranty registration can be done by online. 
The Ministry of Justice and Human Rights subsequently issued guidelines for the smooth process of the fiduciary online registration system. That guideline contains the process for register the fiduciary guarantee certificate online. There are seven stages in the registration process of fiduciary guarantee certificate online, namely:

1. Click the registration menu and fill the information gradually

2. Applicant continues the access by agree to the warning conditions contained on the form by marking the statement.

3. Applicant clicks process to save in database and continue to the next process or click repeat to go to the previous process.

4. After doing submit, it will appear confirmation, that the data successfully processed, then click ok.

5. Applicant prints the registration application proof to make payment to bank perception. If you do not make payments for three days, then the registration application data will be canceled or deleted from the database.

6. The applicant shall pay the registration of fiduciary guarantee in the perception bank and obtain registration proof of fiduciary guarantee from perception bank.

7. To see the list of fiduciary security registrations that have been entered can press the transaction list menu.

For the next step is the certificate printing process. Yet in this fiduciary online registration, there are still some weaknesses, among others: ${ }^{6}$ 


\section{Checking}

In the initial view, we can see the check menu. It turns out that checking is by entering the fiduciary certificate number, so this certainly cannot accommodate the needs of all parties. This is quite vulnerable to the Notary, as it may be possible to register double fiduciary. Therefore, for those who already registered manually, it is still very likely to be registered again online. Date of Fiduciary Guarantee Object Registered. According to the author, the thing that needs to note for fiduciary registration here is when the registered fiduciary object has been registered. Search Menu

2. System data input

a. Data input do in the provided box. In this step, data can be inputted in more than 1.000 characters, but it still cannot receive too much characters

b. If you are going to repair the Notary's name on the system, it should be done by sending a repair request email to the AHU Directorate General E-mail address listed on the system so that it is quite inconvenient.

c. Repeatedly after inputted, the data failed to save and have to re-enter.

d. There is a difference between the display and the input in the guarantee value when entering the 14 digit of number. Similarly, when entering 21 digits. For example, write 70.000 .000 .000 .000 , then the display will be written 70.000.000.000.000,01. 
3. Printing

a. In the process of printing certificates, there may be constraints in printing such as paper jam or when printing suddenly the internet connection is disconnected or power outages, so it cannot be reprinted. Based on this, the Directorate General of AHU needs to reorganize the system in order to reprint the certificate if any constraints as described above are found.

b. Fiduciary Guarantee Certificates are printed not on one page so that it needs to require an expert to print them on a single page.

4. Display of statement and fiduciary guarantee certificate. In the Fiduciary Guaranty Certificate, the name of Fiduciary and Debtor Giver is listed, while the fiduciary guarantee object is not listed at all. Both types, proof of ownership and value. As the statement letter, the subject of the fiduciary guarantee is only written in accordance with the deed only and it does not specify the object of the warranty. As if a motor vehicle requires a police number, frame number, engine number, vehicle color, or other specifications. This creates many problems for the Fiduciary Receiver, as it will be difficult to distinguish from the plenty of Fiduciary Guarantee Certificates. 


\section{CONCLUSION}

Limitation in this research still focus on the weakness of creditor's legal protection, for the research progress in the future can be research about the reconstruction of legal protection for creditor. According to the theoretical review and research result that the writer has done, can be concluded that,

1. Creditor's legal protection on fiducially fiduciary goods registered at the Fiduciary Registration Office is provided in Article 1 paragraph (2), Article 6, Article 7, Article 10 b, Article $11 \mathrm{~s} / \mathrm{d}$ Article 17, Article 20, Article 23 paragraph (2), Article 25 paragraph (2), Article 27 paragraph (1) and (2), Article 29 paragraph (1), Article 30, Article 35, and Article 36 UUJF. While the Creditor is legal protection for fiduciary objects, which is not registered at the Fiduciary Registration Office is in the provisions of Articles 1131, 1132 and 1444 of the Criminal Code. However, in practice, the provisions of Article 11 paragraph (1), Article 17 and Article 29 paragraph (1) and paragraph (2) UUJF cannot be implemented.

2. The weaknesses of Creditor's legal protection for fiduciary security items which is not registered at the current Fiduciary Registry Office are among others:

a. The executorial title takes a long time.

b. It requires a considerable cost.

c. Debtors are not cooperative.

d. The debtor are stalling for execution by making legal remedies such as appeals and plead against first-degree 
court decisions that are deemed to be less than satisfactory.

e. Fiduciary Guarantee Objects are not submitted by the debtor.

\section{REFERENCES}

A.A. Andi Prayitno, 2009., Hukum Fidusia Problematika Yuridis UndangUndang Nomor 42 Tahun 1999, Disertasi, UNTAG Surabaya

A. James Barnes, 1981, AGuide to Bussines Law, Learning Systems Company, Richard. D, Irwin, INC. Hondon Illionis

Bruggink, J.J.H., 1996, Refleksi Tentang Hukum, terjemahan B.Arief Sidharta, Cipta Aditya Bhakti, Bandung

Bryn A Garner, 1999, Black's Law Dictipnary, seventh edition, West Group, ST, Paul, Minn.

http://www.kompasiana.com/ivonedwiratna/kupas-tuntas-fidusia-onlinelangkah-hebat-situs-sibuk-pendulangpnbp 5529389af17e61084e8b4606

Ronny Hanitijo Soemitro, 1990, Metodologi Penelitian Hukum dan Jurimetri, Ghalia Indonesia, Jakarta

Sri Rejeki Hartino, 2007, Hukum Indonesia, Banyumedia Indonesia Publishing, Malang

Sri Soedewi Mascjhoen Sofwan, 1977, Beberapa Masalah Pelaksanaan Lembaga Jaminan Khususnya Fidusia di Dalam Praktek dan Pelaksanaannya di Indonesia, Fakultas Hukum Universitas Gajah Mada, Yogyakarta

Satrio, 2002, Hukum Jaminan, Hak-Hak Jaminan Kebendaan, Citra Aditya Bakt, Bandung

Winda Pebrianti, 2012, Tinjauan Hukum Atas Eksekusi Obyek Jaminan Fidusia Melalui Parate Eksekusi Apabila Obyek Jaminan Beralih Kepada Pihak Ketiga Atau Musnah, Supremasi Hukum, Vol. 21, Nomor 1, Januari 2012 